At the Council meeting held in April, 1930, the following resolution was unanimously passed :-

"The Council in recording in their Minutes that on April 21st, 193\%, Major B. F. S. Baden-Powell, a former President of the Society and for many years a member of Council, had been a member of the Society for fifty years, wish to extend their heartiest good wishes to him for the future, and to congratulate him upon the completion of a record unique in the Society's history."

We are not concerned here with Major Baden-Powell's career outside aviation, only to say that he served on the Nile in 1884 and 1885 , in the South African War 1899-1900, and the Great War 1914-1918. With his death, however, the world has lost one of its most lovable personalities, many have lost a close friend, and the Society has lost a member to whom it must ever owe the deepest debt of gratitude.

\title{
Herbert Charles William Brewer, Associate Fellow, r904-1937.
}

Herbert Charles William Brewer was killed at the early age of 33 in a railway accident at Swanley Junction on June 27 th. The son of the late Rev. H. P. Brewer, he was educated at Lancing College, and Queen's College, Cambridge, where he took an honours degree in engineering. In 1927 he joined the technical staff of the Fairey Aviation Company and showed outstanding ability. He was responsible for a great deal of the design of the Battle, and became an authority on stressed skin construction. Later, at Stockport, he became chief technical officer on the production of the Battle. He took every opportunity of flying on flying trials to obtain a practical insight of the machine with which he had been concerned.

A man who was personally immensely popular and able, the death of $\mathrm{H}$. C. W. Brewer is a serious loss of one who would have risen high in his profession. He was elected an Associate Fellow of the Society in I935.

\section{Reginald Joseph Mitcheld, Fellow, r895-1937.}

The death of Reginald Joseph Mitchell on June IIth, 1937, meant to British aviation the loss of one of its most brilliant designers.

Born at Stoke-on-Trent, he served his apprenticeship with Kerr, Stuart and Co., Ltd., of which he became assistant engineer. In 1916 he joined the Supermarine Aviation Works, Ltd., and became chief engineer and designer in Igro. In 1922 he helped to modify the A.D. flying boat which won the Schneider Trophy for Great Britain, and was concerned in the designs of an amphibian for the Martlesham competition, machines for various foreign governments and the Air Ministry.

In 1924 came Mitchell's first outstanding success with the S.4 which made a world's speed record of 226.76 miles per hour. In 1927 he produced the $S .5$ which won the Schneider Trophy at Venice, and in 1929 the S.6 which won the trophy at Southampton, and in 193i the S.6b which finally won the trophy outright for Great Britain, achievements without parallel in aircraft design. The S.6b made a speed record of $407 \frac{1}{2}$ m.p.h. following the last Schneider Trophy race, and for his work Mr. Mitchell was made a C.B.E.

Despite the intense concentration during those years necessary to produce the fastest seaplanes in the world, Mr. Mitchell was able to design the flying boats Southampton, Scapa and Stranraer, which have been widely ordered by the Royal Air Force. He also designed the Seagull for coastal patrol for the Royal Australian Air Force and the Walrus amphibian for the Fleet Air Arm. A year before his death he produced the Spitfire, one of the fastest single-seater fighters in the service. 